\title{
Immunosuppressive Effect
}

National Cancer Institute

\section{Source}

National Cancer Institute. Immunosuppressive Effect. NCI Thesaurus. Code C40913.

An Immunosuppressive Effect involves interference with, or restraint of, the function of biologic molecules and complexes, or cellular, cell, or tissue components of a normal immune response. 